\title{
STUDY OF THE BUFADIENOLIDES OF THE SKIN SECRETION OF GREEN TOADS (Bufo viridis LAUR, 1758)
}

\author{
I. M. Gella, ${ }^{1}$ D. A. Shabanov, ${ }^{1}$ D. A. Leont'ev, ${ }^{1}$ M. G. Levin, ${ }^{1}$ \\ O. V. Shishkin, ${ }^{1}$ V. N. Baumer, ${ }^{1}$ and E. E. Lakin ${ }^{1}$
}

Translated from Khimiko-Farmatsevticheskii Zhurnal, Vol. 29, No. 7, pp. 41 - 43, July, 1995.

Original article submitted February 3, 1994.

The composition of the skin secretion of Bufo viridis toads, which inhabit the Kharkov region, has been studied in this work. Interest in naturally occurring bufadienolides [1] is due to their cardiotonic and local anesthetic activity [2]. Moderate antiviral and antileukemic activity has been detected in bufadienolides [3]. We have isolated nine bufadienolides ( $I-I X)$ from the steroid fraction of the secretion using column and preparative HPLC. Characteristic signals for the pyrone ring protons were present at $6.2-7.8 \mathrm{ppm}$ in the PMR spectra of all these compounds [4]. Compound I has the composition $\mathrm{C}_{24} \mathrm{H}_{34} \mathrm{O}_{4}\left(\mathrm{MH}^{+}=387\right)$ according to data of elemental analysis and mass spectrometry. Its PMR spectrum agrees with the spectrum of bufalin [5]. Compound II has the composition $\mathrm{C}_{24} \mathrm{H}_{32} \mathrm{O}_{5}$ $\left(\mathrm{MH}^{+}=401\right)$. The characteristic signal for a proton in an epoxide ring is present at $3.51 \mathrm{ppm}$ in its PMR spectrum. This compound corresponds to marinobufagin in its characteristics [5].

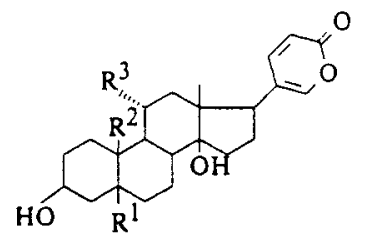

$\begin{array}{cccl} & \mathrm{R}^{1} & \mathrm{R}^{2} & \mathrm{R}^{3} \\ \text { I } & \mathrm{H} & \mathrm{CH}_{3} & \mathrm{H} \text { - bufalin } \\ \text { III } & \mathrm{OH} & \mathrm{CH}_{3} & \mathrm{H} \text { - telocinobufagin } \\ \text { IV } & \mathrm{OH} & \mathrm{CH}_{3} & \mathrm{OH} \text { - gamabufotalin } \\ \text { V } & \mathrm{H} & \mathrm{CH}_{2} \mathrm{OH} & \mathrm{H} \text { - 19-hydroxybufalin } \\ \text { VI } & \mathrm{OH} & \mathrm{CHO} & \mathrm{H} \text {-hellebrigenin }\end{array}$

${ }^{1}$ Kharkov State University, Kharkov, Ukraine.

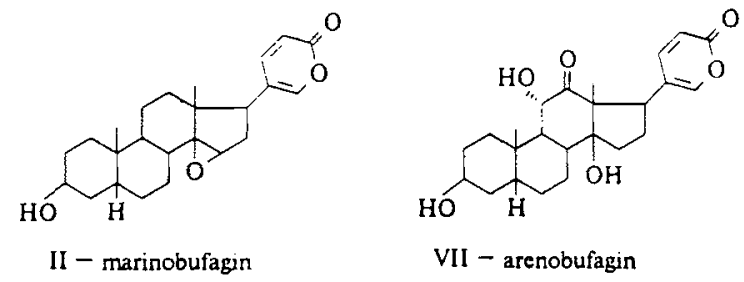<smiles></smiles>

Compounds III $-\mathrm{V}$ have the composition $\mathrm{C}_{24} \mathrm{H}_{34} \mathrm{O}_{5}$ $\left(\mathrm{MH}^{+}=403\right)$ and are all trihydroxy compounds. It follows from the PMR spectrum of compound III that there is only one secondary hydroxyl group in this compound (br. s. $3 \alpha-\mathrm{H}$ at $4.11 \mathrm{ppm}$ ), consequently III is telocinobufagin, its m. p. and PMR spectrum correspond to the literature data in [3]. Signals are present in the RMR spectrum of compound IV for two protons at secondary hydroxyl groups, a broadened singlet for the $3 \alpha-\mathrm{H}$ at $4.15 \mathrm{ppm}$ and a multiplet at $3.8 \mathrm{ppm}\left({ }^{3} \mathrm{~J}=4,10\right.$, and $10 \mathrm{~Hz}$ ). The chemical shift and coupling constants of the latter are characteristic for the geminal proton at the $11 \alpha$-hydroxyl group. Consequently compound IV is gamabufotalin, which was then confirmed by an $x$-ray structural investigation.

The third hydroxyl group of compound $V$ is located at $C-19$ as indicated by the absence of a signal for one angular methyl group and the presence of signals for a hydroxymethyl group as an $\mathrm{AB}$ quartet at $3.5-3.9 \mathrm{ppm}$. Consequently $\mathrm{V}$ is 
19-hydroxybufalin, its PMR spectrum coincides with the data of [5].

Compounds $\mathrm{VI}-\mathrm{IX}$ have the composition $\mathrm{C}_{24} \mathrm{H}_{32} \mathrm{O}_{6}$ $\left(\mathrm{MH}^{+}=417\right)$. Since there are no signals in their PMR spectra for protons located either at a double bond or a 14,15ß-epoxide ring, then according to their empirical formula compounds VI - IX contain a carbonyl and three hydroxyl groups. A singlet is observed at $9.99 \mathrm{ppm}$, characteristic of an aldehyde group proton, in the PMR spectrum of VI in place of the signal for a 19- $\mathrm{CH}_{3}$ group. The presence of only one signal for a proton near a secondary hydroxyl group (br. s. $3 \alpha-\mathrm{H}$ at $4.19 \mathrm{ppm}$ ) indicates that compound VI is hellebrigenin, its PMR spectrum mainly agrees with that described in $[3,5]$. The PMR spectrum of compound VII in $\mathrm{CDCl}_{3}$ does not at first sight correspond to the structure proposed for the trihydroxycarbonyl compound since there are four signals and not two on the low field region $3.8-4.4 \mathrm{ppm}$, where the signals for protons at hydroxyl groups are usually observed, viz. $3.81 \mathrm{ppm}$ $(\mathrm{d}, 1 \mathrm{H}), 4.11 \mathrm{ppm}(\mathrm{m}, 2 \mathrm{H})$, and $4.32 \mathrm{ppm}(\mathrm{d} \mathrm{d}, 1 \mathrm{H})$. The signal at $3.81 \mathrm{ppm}$ disappeared in $\mathrm{CD}_{3} \mathrm{OD}$, the signal at $4.36 \mathrm{ppm}$ was converted into a doublet, and the multiplet at $4.11 \mathrm{ppm}$ was converted into a quartet at $4.15 \mathrm{ppm}$ (with coupling constants 6 and $9 \mathrm{~Hz}$ ) and a broadened singlet at $4.05 \mathrm{ppm}$ $(3 \alpha-H)$. These data are in agreement with the published PMR spectrum of arenobufagin [6] wlth assignment of the doublet at $3.81 \mathrm{ppm}$ to the proton of the $11 \alpha-\mathrm{OH}$ group and the quartet at $4.11 \mathrm{ppm}$ to the $17 \alpha-\mathrm{H}$.

In the PMR spectrum of compound VIII (about $2 \mathrm{mg}$ isolated) there were signals for two pritins at secondary hydrixyl groups, a briadened singlet for the $3 \alpha-\mathrm{H}$ at $4.11 \mathrm{ppm}$ and a singlet at $3.9 \mathrm{ppm}$. The signals for the $18-$ and $19-\mathrm{CH}_{3}$ groups were located at 0.5 and $1.25 \mathrm{ppm}$. Only bufanenogin (as the diacetate) [4] and its 5 $\beta$-hydroxy analog, isolated from glow-worms [7], have chemical shifts close to those of the angular methyl groups. Based on this we suggest that compound VIII is bufanenogin. The structure of compound IX was not established.

TABLE 1. Composition of the Skin Secretion of Green Toads (Bufo viridis L.)

\begin{tabular}{lccccc}
\hline \multirow{2}{*}{ Compound } & \multicolumn{4}{c}{ Relative content, \% } \\
\cline { 2 - 3 } & \multicolumn{2}{c}{ Zorbax CN } & & \multicolumn{2}{c}{ Zorbax Sil } \\
\cline { 2 - 3 } \cline { 6 - 6 } & \multicolumn{1}{c}{1992} & $199 j$ & & 1992 & 1993 \\
\hline Bufalin & 2.7 & 2.0 & & \\
Marinobufagin & 20.9 & 24.7 & & 22.8 & 23.1 \\
Telocinobufagin & 12.1 & 10.4 & & 12.8 & 12.6 \\
Hellebrigenin & 5.1 & 3.0 & & 4.5 & 2.4 \\
Arenobufagin & 14.4 & 13.1 & & 14.1 & 14.8 \\
Gamabufotalin & 36.2 & 44.9 & & 37.2 & 43.8 \\
\hline
\end{tabular}

\footnotetext{
"In relarive peak area.

"Together with 19-hydroxybufalin on Zorbax $\mathrm{CN}$.
}

The bufadienolides isolated by us were then used as markers in the development of a procedure for the chromatographic analysis of the total extract of Bufo viridis secretion. The method of determining the composition of bufadienolides developed in [8] comprized extraction of steroids from the secretion, preliminary separation of them into three fractions by TLC, and subsequent analysis by HPLC on a reversed phase column (with a different mobile phase composition for each fraction). We obtained satisfactory results in a parallel analysis of total bufadienolides on a normal phase column of Zorbax Sil in $\mathrm{CHCl}_{3}$-thanol and a reversed phase column of Zorbax $\mathrm{CN}$ in $\mathrm{CH}_{3} \mathrm{CN}-\mathrm{H}_{2} \mathrm{O}$. Conducting the analysis on two columns was necessary since 19-hydroxybufalin overlaps hellebrigenin on the Zorbax CN column, and bufalin and marinobufagin are resolved unsatisfactorily on Zorbax Sil. Parallel analysis on two different columns provides a complete resolution of all the main components of the secretion. Only one of the minor components isolated by us, viz. bufanenogin, was not determined in these systems since it overlaps gamabufotalin on the Zorbax $\mathrm{CN}$ column and hellebrigenin on Zorbax Sil.

As is evident from the results presented in Table 1 the main component of the secretion is gamabufotalin and the composition of the bufadienolides in the specimens investigated by us differed from the data published previously in $[9,10]$. Bufalin, marinobofagin, resibufogenin, and cinobufagin were identified in the secretion from green toads inhabiting the central zone of Russia [9]. These results, which are based on qualitative reactions and data of paper chromatography, are unreliable. Karinobufagin, telocinobufagin, hellebrigenin, and arenobufagin were identified in [10] as the main components of the secretion. The main component of the secretion was arenobufagin but gamabufotalin was in general not detected.

The green toad is a widespread and extremely polymorphic species. Many of its populations have an obscure taxonomic status [11]. In addition appreciable intraspecies differences in the composition of skin secretions have been recorded in the related species Bufo regularis [12]. On this basis we suggest that the differences of our results are explained by the fact that an appreciably different form of Bufo viridis was studied in [10].

\section{EXPERIMENTAL PART}

Parotid secretion (parotid or suprascapular glands) was obtained by the generally accepted procedure [13] from adult green toads and was dried over $\mathrm{CaCl}_{2}$. The secretion investigated had been obtained from a representative selection of several hundred specimens of a nominated subspecies of green toad (Bufo viridis) collected by us in the Kharkov area in May - June 1992 and 1993. For the identification of the bu- 
fadienolides present in them the bufadienolides and the sterols accompanying them were extracted from $10 \mathrm{~g}$ dried parotid secretion of green toads with a $\mathrm{CHCl}_{3}-\mathrm{CH}_{3} \mathrm{OH}(4: 1)$ mixture. The sterols were separated from bufadienolides by distribution in the system $\mathrm{CH}_{3} \mathrm{OH}$-hexane. The steroids remaining in the methanol phase were separated, after evaporation, by chromatography on silica gel on a $\mathrm{CHCl}_{3}-\mathrm{C}_{2} \mathrm{H}_{5} \mathrm{OH}$ gradient. The separate fractions were separated into individual compounds by preparative HPLC on a reversed phase column.

Separation and analysis of bufadienolides was carried out with a Waters liquid chromatograph with a UV detector recording at $300 \mathrm{~nm}$. Preparative separation of bufadienolide fractions was carried out on a column of Diasorb $\mathrm{C}_{16} \mathrm{~T}$, $250 \times 10 \mathrm{~mm}$ with $\mathrm{CH}_{3} \mathrm{CN}-\mathrm{H}_{2} \mathrm{O}$ as mobile phase. The analytical separation was carried out on a column of Zorbax Sil $4.6 \times 150 \mathrm{~mm}$ eluting with $\mathrm{CHCl}_{3}-\mathrm{C}_{2} \mathrm{H}_{5} \mathrm{OH}(96: 4)$ and a column of Zorbax $\mathrm{CN} 4.6 \times 250 \mathrm{~mm}$ eluting with $\mathrm{CH}_{3} \mathrm{CN}-\mathrm{H}_{2} \mathrm{O}$ (25:75).

Fast atom ionization mass spectra were taken on a MI 1201 series spectrometer (Élektron Production Association, Sumy, Ukraine) in a glycerol matrix at a primary beam energy of $3.5 \mathrm{keV}$. The PMR spectra were taken on a Bruker AC 200 (Germany) spectrometer in $\mathrm{CDCl}_{3}$ and $\mathrm{CD}_{3} \mathrm{OD}$.

Crystals of compound IV for $\mathrm{x}$-ray structural investigation were obtained by two recrystallizations from acetonitrile and were solvated $1: 1$. The crystal system was rhombic. At $20^{\circ} \mathrm{C} a=10.520(3), b=13.717(5), c=16.120(4) \AA$, $V=2326(1) \AA^{3}, d_{\text {calc }}=1.327 \mathrm{~g} / \mathrm{cm}^{3}$, space group $\mathrm{P} 22_{1} 2_{1}$, $Z=4$. The unit cell parameters and the intensities of 1450 independent reflections with $\mathrm{F}>6 \sigma(\mathrm{F})$ were measured on a Siemens $\mathrm{P} 3 / \mathrm{PC}$ automatic four-circle diffractometer $\left(\mathrm{MoK}_{\alpha} \mathrm{ra}-\right.$ diation, graphite monochromator, $2 \theta_{\max }=50^{\circ}$ ).

The structure was refined by the direct method using the Sheltx Plus set of programs.

Compound I (bufalin), white amorphous powder. $\mathrm{C}_{24} \mathrm{H}_{34} \mathrm{O}_{4}$. Mass spectrum, $m / z: 387\left(\mathrm{MH}^{+}\right)$. PMR spectrum, $\delta$, ppm: $0.7 \mathrm{~s}(18-\mathrm{Me}), 0.946 \mathrm{~s}(19-\mathrm{Me}), 2.43 \mathrm{~m}(17 \alpha-\mathrm{H}), 4.13 \mathrm{~s}$ $(3 \alpha-H), 6.26 \mathrm{~d}(\mathrm{~J}=9.6 \mathrm{~Hz}), 7.23 \mathrm{~d}(\mathrm{~J}=2.3 \mathrm{~Hz}), 7.82 \mathrm{dd}$ $(\mathrm{J}=9.6,2.3 \mathrm{~Hz})$.

Compound II (marinobufagin), colorless crystalline product, m. p. $224-226^{\circ} \mathrm{C}$ (acetone), literature m. p. $222-224^{\circ} \mathrm{C}$ [7]. $\mathrm{C}_{24} \mathrm{H}_{32} \mathrm{O}_{5}$. Mass spectrum, $m / z ; 401\left(\mathrm{MH}^{+}\right)$. PMR spectrum, $\delta$, ppm: $0.78 \mathrm{~s}(18-\mathrm{Me}), 0.99 \mathrm{~s}(19-\mathrm{Me})$, $3.51 \mathrm{~s}(15 \alpha-\mathrm{H}), 4.19 \mathrm{~s}(3 \alpha-\mathrm{H}), 6.25 \mathrm{~d}(\mathrm{~J}=9.7 \mathrm{~Hz}), 7.24 \mathrm{~d}$ $(\mathrm{J}=2.7 \mathrm{~Hz}), 7.78 \mathrm{~d} \mathrm{~d}(\mathrm{~J}=9.7,2.7 \mathrm{~Hz})$.

Compound III (telocingbufagin), colorless crystalline product, m. p. $151-155^{\circ} \mathrm{C}$, literature m. p. $154-157^{\circ} \mathrm{C}$ $1204-206^{\circ} \mathrm{C}$ [3]. $\mathrm{C}_{24} \mathrm{H}_{34} \mathrm{O}_{5}$. Mass spectrum, $m / z: 403\left(\mathrm{MH}^{+}\right)$. PMR spectrum, d, ppm: 0.695 s (18-Me), 0.93 s (19-Me), $2.46 \mathrm{~m}(17 \alpha-\mathrm{H}), 4.17 \mathrm{~s}(3 \alpha-\mathrm{H}), 6.25 \mathrm{~d}(J=9.7 \mathrm{~Hz}), 7.23 \mathrm{~d}$ $(\mathrm{J}=2.5 \mathrm{~Hz}), 7.83 \mathrm{~d} \mathrm{~d}(\mathrm{~J}=9.7,2.5 \mathrm{~Hz})$.

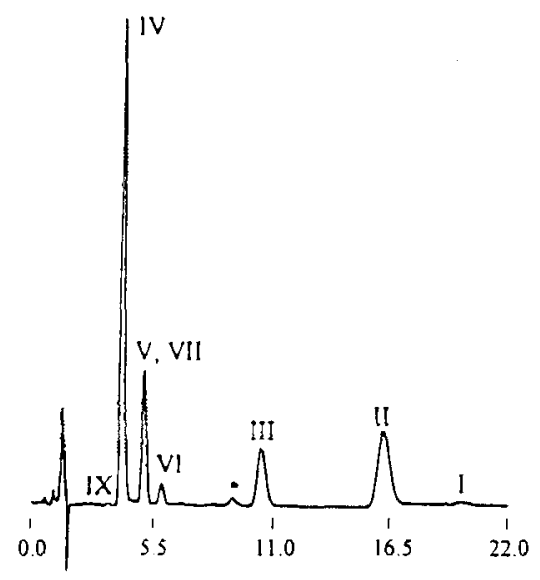

Fig. 1. The HPLC of the bufadienolide fraction of green toad secretion (collected in 1993) on a column of Zorbax CN $4.6 \times 150 \mathrm{~mm}$, mobile phase $\mathrm{CH}_{3} \mathrm{CN}-\mathrm{H}_{2} \mathrm{O}$ (25 75 vol. \%), $1.5 \mathrm{ml} / \mathrm{min}$, UV detector, $300 \mathrm{~nm}$. Abscissa) Retention time, min. *) Unidentified component.

Compound IV (gamabufotalin), colorless crystalline product, m. p. $261-263^{\circ} \mathrm{C}$, literature m. p. $261-264^{\circ} \mathrm{C}$ [3]. $\mathrm{C}_{24} \mathrm{H}_{34} \mathrm{O}_{5}$. Mass spectrum, $m / z: 403\left(\mathrm{MH}^{+}\right)$. PMR spectrum, $\delta$, ppm: $0.74 \mathrm{~s}(18-\mathrm{Me}), 1.075 \mathrm{~s}(19-\mathrm{Me}), 2.52 \mathrm{~m}(17 \alpha-\mathrm{H})$, $3.79 \mathrm{~m}(11 \beta-\mathrm{H}, \mathrm{J}=10.0,10.0,4.0 \mathrm{~Hz}), 4.15 \mathrm{~s}(3 \alpha-\mathrm{H}), 6.26 \mathrm{~d}$ $(\mathrm{J}=9.8 \mathrm{~Hz}), 7.25 \mathrm{~d}(\mathrm{~J}=2.6 \mathrm{~Hz}), 7.79 \mathrm{~d} \mathrm{~d}(\mathrm{~J}=9.8,2.6 \mathrm{~Hz})$.

Compound V (19-hydroxybufalin), colorless oil. $\mathrm{C}_{24} \mathrm{H}_{34} \mathrm{O}_{5}$. Mass spectrum, $m / z: 403\left(\mathrm{MH}^{+}\right)$. PMR spectrum, $\delta$, ppm: $0.7 \mathrm{~s}(18-\mathrm{Me}), 2.45 \mathrm{~m}(17 \alpha-\mathrm{H}), 3.49 \mathrm{~d}$ and $3.87 \mathrm{~d}$ $\left(19-\mathrm{CH}_{2}, \mathrm{~J}=10.9 \mathrm{~Hz}\right), 4.13 \mathrm{~s}(3 \alpha-\mathrm{H}), 6.26 \mathrm{~d}(\mathrm{~J}=9.8 \mathrm{~Hz})$, $7.22 \mathrm{~d}(\mathrm{~J}=2.6 \mathrm{~Hz}), 7.83 \mathrm{~d} \mathrm{~d}(\mathrm{~J}=9.8,2.6 \mathrm{~Hz})$.

Compound VI (hellebrigenin), colorless amorphous product. $\mathrm{C}_{24} \mathrm{H}_{34} \mathrm{O}_{6}$. Mass spectrum, $m / z: 417\left(\mathrm{MH}^{+}\right)$. PMR spectrum, $\delta$, ppm: $0.69 \mathrm{~s}$ (18-Me), $2.47 \mathrm{~m}(17 \alpha-\mathrm{H}), 4.19 \mathrm{~s}$ $(3 \alpha-\mathrm{H}), 6.26 \mathrm{~d}(\mathrm{~J}=9.7 \mathrm{~Hz}), 7.23 \mathrm{~d}(\mathrm{~J}=2.6 \mathrm{~Hz}), 7.8 \mathrm{dd}$ $(\mathrm{J}=9.7,2.6 \mathrm{~Hz}), 9.99 \mathrm{~s}(19-\mathrm{H})$.

Compound VII (arenobufagin), colorless crystalline product, m. p. $213-215^{\circ} \mathrm{C}$ (acetone), literature $\mathrm{m}$. p. $208-213^{\circ} \mathrm{C}[6], 222-228^{\circ} \mathrm{C}$ [6]. $\mathrm{C}_{24} \mathrm{H}_{34} \mathrm{O}_{6}$. Mass spectrum, $m / z: 417\left(\mathrm{MH}^{+}\right)$. PMR spectrum $\left(\mathrm{CDCl}_{3}\right), \mathrm{d}, \mathrm{ppm}: 0.92 \mathrm{~s}$ (18-Me), $1.18 \mathrm{~s}(19-\mathrm{Me}), 3.81 \mathrm{~d}(1 \mathrm{l}-\mathrm{OH}, \mathrm{J}=3 \mathrm{~Hz}), 4.11 \mathrm{~m}$ $(17 \alpha-\mathrm{H}, 3 \alpha-\mathrm{H}), 4.32 \mathrm{dd}(11 \beta-\mathrm{H}, \mathrm{J}=10.8,3 \mathrm{~Hz}), 6.29 \mathrm{~d}$ $(\mathrm{J}=9.8 \mathrm{~Hz}), 7.39 \mathrm{~d}(\mathrm{~J}=2.6 \mathrm{~Hz}), 7.72 \mathrm{~d} \mathrm{~d}(\mathrm{~J}=9.8,2.6 \mathrm{~Hz})$. PMR spectrum $\left(C D_{3} O D\right), \delta$, ppm: $0.9 \mathrm{~s}(18-\mathrm{Me}), 1.17 \mathrm{~s}$ (19-Me), $4.05 \mathrm{~s}(3 \alpha-\mathrm{H}), 4.15 \mathrm{dd}(17 \alpha-\mathrm{H}, \mathrm{J}=9.0,6.0 \mathrm{~Hz})$, $4.36 \mathrm{~d}(11 \beta-\mathrm{H}, \mathrm{J}=10.5 \mathrm{~Hz}), 6.3 \mathrm{~d}(\mathrm{~J}=10 \mathrm{~Hz}), 7.5 \mathrm{~d}$ $(\mathrm{J}=2.9 \mathrm{~Hz}), 7.96 \mathrm{~d} \mathrm{~d}(\mathrm{~J}=10,2.9 \mathrm{~Hz})$.

Compound VIII (bufanenogin), amorphous product. $\mathrm{C}_{24} \mathrm{H}_{34} \mathrm{O}_{6}$. Mass spectrum, $m / z: 417\left(\mathrm{MH}^{+}\right)$. PMR spectrum, $\delta$, ppm: $0.5 \mathrm{~s}(18-\mathrm{Me}), 1.25 \mathrm{~s}(19-\mathrm{Me}), 2.63 \mathrm{~d}(\mathrm{~J}=12.2 \mathrm{~Hz})$, $3.23 \mathrm{dd}(17 \alpha-\mathrm{H}, \mathrm{J}=9.0,6.0 \mathrm{~Hz}), 3.9 \mathrm{~s}(12 \alpha-\mathrm{H}), 6.25 \mathrm{~d}$ $(\mathrm{J}=9.7 \mathrm{~Hz}), 7.36 \mathrm{~d}(\mathrm{~J}=2.8 \mathrm{~Hz}), 7.7 \mathrm{~d} \mathrm{~d}(\mathrm{~J}=9.7,2.8 \mathrm{~Hz})$. 


\section{REFERENCES}

1. N. Horiger, D. Zivanov, H. H. A. Linde, and K. Meyer, Helv. Chim. Acta, 55, 2549 - 2562 (1972).

2. B. S. Low, "Evidence from parotid gland secretions," in: Evolution in Genus Bufo, Dallas (1972), pp. $244-265$.

3. J. D. Wang, T. Narui, S. Takatsuki, et al., Chem. Pharm. Bull., 39(8), $2135-2137$ (1991).

4. L. Gsell and C. Tamm, Helv. Chim. Acta, 52, 551 - 560 (1969).

5. R. Verpoorte, Phan-quoc-Kihn, and A. B. Svendsen, J. Nat. Products, 43(3), $347-352$ (1980).

6. J. Meinwald, D. F. Weimer, and T. Eisner, J. Am. Chem. Soc., 101(11), $3055-3060$ (1979).
7. M. Götz, D. F. Wiemer, W. Le Roy Haynes, et al., Helv. Chim. Acta, 62(5), 1396 - 1400 (1979).

8. K. Shimada, M. Hasegawa, K. Hasebe, et al., Chem. Pharm. Bull., 24(12), 2995 - 3000 (1976).

9. V. N. Krylov, L. V. Yunina, and I. I. Lysova, Mechanisms of Action of Zootoxins [in Russian], Gorky (1977), pp. 150-154.

10. K. Shimada, N. Ishii, and T. Nambara, Chem. Pharm. Bull., 34(8), $3453-3457$ (1976).

11. P. Roth, "An overview of the systematics of the Bufo viridis group in Middle and Central Asia," in: Studies of Herpetology, Prague (1986), pp. $130-136$.

12. B. S. Low, Comp. Biochem. Physiol., 26, 245 - 257 (1968).

13. B. N. Orlov, D. B. Gelashvili, and A. K. Ibragimov, Poisonous Animals and Plants of the USSR [in Russian], Moscow (1990). 